\title{
Factors of ability, communication, grievances, and personal optimism as predictors of student satisfaction, involvement, and alienation: An ecological dissonance interpretation
}

\author{
DUANE I. MILLER and JEFF S. TOPPING \\ Mississippi State University, Mississippi State, Mississippi
}

\begin{abstract}
The present study examined the variables of ability, communication, grievances, and personal optimism as predictors of student satisfaction, involvement, and alienation. Weak but statistically significant correlations occurred between openness of communication and alienation $(r=-.11)$, personal optimism and involvement $(r=-.16)$, and grievances and student satisfaction $(r=-.17)$. It was concluded that these results could have been loosely deduced from ecological dissonance theory (Miller, Topping, \& Wells-Parker, 1989).
\end{abstract}

The hypothesis that organizations can be characterized as possessing climates, which may be used to distinguish one organization from another and which influence the behavior of individuals within the organizations, has received considerable attention (Fleishman, 1953; Forehand \& Gilmer, 1964; Lewin, Lippitt, \& White, 1939; D. I. Miller, Majors, Giesen, \& Topping, 1990; Schneider, 1975). Although the definitions and corresponding theories vary from researcher to researcher, and this disagreement has generated criticism, some still believe that the concept of climate is important enough to warrant the continued development of theoretical models and operational definitions (D. I. Miller, Topping, \& Wells-Parker, 1989).

One new theory, ecological dissonance theory, was developed to further understanding of the complexity of the interplay of systems that provide both the structure and the dynamics of climates (D. I. Miller, 1989; D. I. Miller et al., 1989). Of special concern to ecological dissonance theory is the friction that is generated by conflicting systems. For instance, in a university, it is possible for the research system, and the desire to receive external funding to support it, to conflict with the instructional system. This is especially likely when the university has limited resources. A similar conflict can arise in the sales division of firms when the salesperson receives performance evaluation pressure from his or her organization, yet the friends of the salesperson are the customers he or she serves. In this situation, the organizational system is in conflict with the salesperson's social affiliation system.

Although ecological dissonance theory has typically been investigated by using measures of equal opportunity as operational definitions, other dimensions of ecological dissonance exist. One such dimension relates to the

Requests for reprints should be addressed to D. I. Miller, P.O. Box 6161, Mississippi State, MS 39762-6161. goals of an organization. If the goals of the organization are consonant with the goals of the individuals in the organization, there probably will be an atmosphere of optimism (i.e., low ecological dissonance) in the organization. For instance, a university unit that prepares students for successful employment will create an optimistic environment for those students who place high priority on employment, especially if employment opportunities exist. Another dimension concerns leadership style. In organizations with democratic leadership styles, one might expect low ecological dissonance, as manifested by more harmony and fewer grievances on the part of the participants. Also, organization with open communication channels will probably be able to ameliorate any existing ecological dissonance or conflict and, as a result, raise the morale of its members. A third dimension concerns the match, or consonance, between individual ability and organizational goals. An organization with members who perceive themselves as having the necessary abilities to succeed in the organization will be characterized by high levels of morale.

In summary, one might expect high levels of participant morale (i.e., low alienation, high involvement, and high satisfaction) in organizations with open communication channels, low levels of grievances, and high levels of environmental and personal optimism. The purpose of the present study was to examine various factors of ecological dissonance as measured by the expectations concerning the outcomes resulting from majoring in a given field, estimating financial and intellectual ability, and perceiving the freedom to discuss problems as they relate to student satisfaction, involvement, and alienation in one's academic major. Specifically, it was predicted that:

1. In situations with high levels of perceived grievances, there would be low morale scores; that is, subjects would produce low satisfaction scores, low involvement scores, and high alienation scores. 
2. When subjects perceived that they had the required personal ability and financial ability to continue with their major, they would be more satisfied with, more involved in, and less alienated from their majors.

3. When subjects felt that they had the freedom to discuss their problems with their advisors, faculty, and department heads, they would be more satisfied with, more involved in, and less alienated from their majors.

4. When subjects had positive expectations concerning the future benefits to be derived from majoring in their fields, they would be more satisfied with, more involved in, and less alienated from their majors.

\section{METHOD}

\section{Subjects}

A total of 309 male and female subjects from the Colleges of Arts and Sciences, Engineering, and Education at Mississippi State University were surveyed. Of these subjects, 126 were seniors, 75 were juniors, 54 were sophomores, and 32 were freshmen; the remainder were graduate students.

\section{Stimulus Materials and Procedure}

The survey contained 18 items from Brayfield and Rothe's (1951) Job Satisfaction Index, 5 items from G. A. Miller's (1967) Alienation Scale, 6 items from Lodahl and Kesner's (1965) Index of Job Involvement, and 6 demographic items. The subjects also responded to items designed to determine if they expected positive outcomes from majoring in their fields, if they felt they had the intellectual ability and financial ability to be successful in their chosen majors, if they perceived a need to complain on behalf of themselves and others in their same major, and if they felt that appropriate communication channels were available for their use. The items are available from the senior author.

\section{RESULTS}

When student satisfaction, involvement, and alienation were correlated with the items concerning openness of communication, only alienation significantly correlated with openness of communication $[r(307)=-.11, p<$ .05]. A Pearson product-moment correlation applied to the variable representing positive expectations of outcomes from majoring in a given field and the three criterion measures revealed a significant correlation between positive expectations and involvement $[r(307)=-.16, p<.05]$. Since high scores on the involvement measure indicated low involvement, the correlation was in the expected direction. In the correlational analysis between grievances and the three measures of morale, the correlation between grievances and satisfaction was significant $[r(307)=$ $-.17, p<.06$ ]. The correlations between ability estimates and the measures of morale, along with all other correlations, were statistically insignificant.

\section{DISCUSSION}

Although all correlations that were statistically significant were weak, they were in the predicted direction. Furthermore, these predictions could have been loosely derived from the propositions of ecological dissonance theory (D. I. Miller et al., 1989). Specifically, with the use of grievances as an indication of dissonance, it was expected that participants would report lower morale when they simultaneously indicated a need to express grievances. D. I. Miller et al. (1990) reported a similar relationship between the equal-opportunity measure of ecological dissonance and student satisfaction. In addition, with the use of openness of communication as a predictor of functional levels of ecological dissonance. it was predicted that higher levels of morale would occur in systems where the participants perceived that they were free to express any grievances that they might have. It is assumed that the open communication of grievances serves the function of venting or releasing the energy generated by ecological dissonance. Finally, by using the expression of optimism concerning the opportunities generated by a given major as an index of ecological dissonance, it was predicted that students morale would be correlated with students' optimism about their future.

In conclusion, it is asserted that some of the measures used in the present study may be weak predictors of morale (i.e., student satisfaction, involvement, and alienation). Furthermore, although other theories could be used to predict the individual results, ecological dissonance theory (D. I. Miller et al.. 1989) is offered as a theory broad enough to explain all the significant results found in the present study.

\section{REFERENCES}

Brayfield, A. H., Rothe, H. F. (1951). An index of job satisfaction. Journal of Applied Psychology, 35, 307-311.

Fleishman, E. A. (1953). Leadership climate, human relations training and supervisory behavior. Personnel Psychology, 6, 205-222.

Forehand, G. A.. Gilmer, B. (1964). Environmental variation in studies of organizational behavior. Psychological Bulletin. 62, 361-381.

Lewin, K.. Lippitt, R. \& White, R. K. (1939). Patterns of aggressive behavior in experimentally created social climates. Journal of Social Psychology, 10, 271-299.

LODAhL. T. M., KeSNer, M. (1965). The definition and measurement of job involvement. Journal of Applied Psychology, 49. 24-33.

MiLLER, D. I. (1989). The ecological psychology of the small town. Psychology: A Journal of Human Behavior, 26, 11-14

Miller, D. I., Majors, M., Giesen, M., \& Topping, J. S. (1990). The Hooper equal opportunity measure: An operational definition of ecological dissonance theory. Bulletin of the Psychonomic Societv. 28, $164-166$.

Miller, D. I., Topping, J. S., \& Wells-Parker, E. N. (1989). Ecological dissonance and organizational climate. Psychological Reports, 64, 163-166.

Miller, G. A. (1967). Professions in bureaucracy: Alienation among industrial scientists and engineers. American Sociological Review', 32. 755-768.

SChneider, B. (1975). Organizational climates: An essay. Personnel Psychology, 28, 447-479.

(Manuscript received May 25, 1990.) 